University for Business and Technology in Kosovo

UBT Knowledge Center

UBT International Conference

2015 UBT International Conference

Nov 7th, 9:00 AM - 5:00 PM

\title{
Law as an Instrument for Political Influence over Kosovo's Public Broadcaster
}

Gjylije Rexha

University for Business and Technology, gjylije.rexha@ubt-uni.net

Follow this and additional works at: https://knowledgecenter.ubt-uni.net/conference

Part of the Communication Commons

\section{Recommended Citation}

Rexha, Gjylije, "Law as an Instrument for Political Influence over Kosovo's Public Broadcaster" (2015). UBT International Conference. 13.

https://knowledgecenter.ubt-uni.net/conference/2015/all-events/13

This Event is brought to you for free and open access by the Publication and Journals at UBT Knowledge Center. It has been accepted for inclusion in UBT International Conference by an authorized administrator of UBT Knowledge Center. For more information, please contact knowledge.center@ubt-uni.net. 


\title{
Law as an Instrument for Political Influence over Kosovo's Public Broadcaster
}

\author{
Gjylije Rexha \\ Faculty of Media and Communication, UBT \\ gjylije.rexha@ubt-uni.net
}

\begin{abstract}
Politics uses its instruments to exert influence over the public media. The main instrument that politics uses is the law - as the grounds which regulate the rapport between the public media and the political power. Examples of the most independent public broadcasters can be found in those countries where politics has adopted and executed such legislation that limits the possibility of politics to exert influence over the main components related to the independence of the public media. In the case of the Radio Television of Kosovo - RTK, politics has failed to follow this practice notwithstanding that RTK has been established based on models of the public broadcasters in countries representing the Democratic -Corporatist and North-Atlantic Models. The political power in Kosovo has used the law as an instrument to exert influence on the two main parameters related to the editorial independence of the broadcaster: the manner of financing and the election of the medium's Board. The model of influence has not changed in spite of changes made within the RTK's founding institution or by changes of political forces in power. RTK went through only one five-year spell of pre-payment during which time it underwent the transformation into a company that is financially independent. However, that same period demonstrated that financial independence alone without managerial independence is no guarantee for editorial independence. The consequences of such influence are reflected on the editorial policies and program content, which render this broadcaster that has the legal status "public" into a medium that serves as a "loudspeaker" for the voice of the political power.
\end{abstract}

Key words: public broadcaster, RTK, editorial independence, political instruments

\section{Introduction}

The Radio Television of Kosovo (RTK) is the only mass medium in Kosovo the functioning of which is regulated by a special law. From the onset of its functioning, the RTK was widely appraised by international and Kosovo political factors as an institution of a special importance in the media and social realms. The RTK is the only media in Kosovo bearing the legal status of the public media outlet, and the status of the media outlet with the biggest influence on the public opinion because of its viewership. These elements have determined the importance and attention that international and Kosovo decision-making political factors have placed up on RTK. The attention on RTK was indicated by means of regulations, rules, and court decisions. Such attention has affected its activities and editorial policies. The Law on RTK has been amended three times from its establishment in 1999. UNMIK Regulation on the Establishment of RTK (UNMIK REG 2001/13) having the power of a law, was stipulated in 2001. ${ }^{118}$ This created the grounds for the "Kosovarization" of the management and funding of RTK. The Regulation created an opportunity for funding through subscription and legalized the powerful link between politics and the public broadcaster. The first Law on the RTK, the one that finalized the process of "Kosovarization" was adopted in 2006. This Law recognized the Assembly of Kosovo as the founding institution of the RTK, as an interim self-governing institution and provided to the RTK the opportunity to be led by an elected - not appointed - Board which, for the first time ever, comprised of Kosovars only. This law was never fully applied. The political class

${ }^{118}$ In the first two years, the public broadcaster of Kosovo functioned based on UNMIK Pillar III decisions (OSCE-Organization for Security and Cooperation in Europe), and was managed by internationals. 
in Kosovo demonstrated it was not ready to accept the functioning of the public media outlet independently of politics, although they had adopted the Law guaranteeing the very same independence.

After the proclamation of the independence of Kosovo (17 February 2008) RTK cont inued to function based on the inapplicable law from the period of the protectorate and this continued until 2012. During this period, the subscription fee was terminated and the direct funding every six months from the state budget was offered as an interim solution. The change in the funding method created a direct financial dependency, a component that is directly reflected on the editorial dependency. Meanwhile, the Law of 2012 created a direct dependence of the RTK leadership on the political power through the centralization of the process for the selection of the RTK Board members who were to be elected only by the members of the Assembly of the Republic of Kosovo. According to the law based on which RTK carries out its mandate, the RTK appears as the scholars describe the public broadcasters: "the most highly structured sort of media organization and at the same time the most political". ${ }^{119}$

\section{Political Influence through the Funding Model}

Studies on public broadcasters in different countries demonstrate that in the absolute majority of cases, "the isolation of the public broadcaster by the control of the political majority"120, is achieved with difficulty when the media depend on the funds allocated by the Government through the state budget. "The cleanest broadcasters" are found in the countries of the Democratic Corporatist Model, whereas the broadcaster that are the most influenced by politics are found in the Polarized Pluralist Model Mediterranean countries where the broadcasters are by and large dependant on the funds allocated by the Government or the parliament through the state budget.

In the case of RTK, the funding model has changed several times from the time it was established. ${ }^{121}$ UNMIK Regulation 2001/13 provided the legal grounds to begin RTK financing through subscription fee. ${ }^{122}$ In 2003, RTK and the Kosovo Energy Corporation reached an agreement based on which subscription fee for RTK would be paid via electricity bills. Once the collection of the subscription fee of $€ 3.5$ began, the funding scheme for the RTK changed. In its fifth year of functioning, RTK managed to be no longer dependant on the Kosovo budget or donor money. This funding model was continued by the first Law on RTK adopted in January 2006 by the Assembly of Kosovo. In Chapter III, Funding of RTK, the law determined that the RTK shall be funded mainly by the Public Broadcasting Fee. ${ }^{123}$ Article 20 defined the relations between the RTK and the agents to collect subscription fee, nonetheless not excluding the possibility of changing the previous collection agent. "The RTK Board is authorized to decide which organization it deems suitable, including the Kosovo Electric Corporation and other agencies, to provide services necessary for the collection of the fee."124

${ }^{119}$ Kuhn, R., Broadcasting and politics in Western Europe, Frank Cass and Company Limited, London 1985, pg 12

${ }^{120}$ Hallin, D., Mancini, P., Comparing Media Systems - Three models of media and politics, Cambridge University Press, UK 2004, 165

${ }^{121}$ Among the main donors are important international organizations and governments. Japan has awarded \$15.2MIL for the equipment in the RTK studios and for the broadcasters for KTTN. The European Agency for Reconstruction (EAR) has awarded direct assistance to support RTK in 2001 with $€ 2.5 \mathrm{MIL}$ and in 2002 the amount of $€ 1.5 \mathrm{MIL}$. The Swiss Corporation has supported the radio stations: Radio Kosova and Radio Blue Sky in five stages until 2005, with a total amount of CHF 5 MIL. The Swedish International Development Agency (SIDA) has mainly provided support to the RTK programs for minorities. In 2001-2002 the amount was $€ 300.000$ annually. ( Kaufman, Joshua, Kosovo media assessment, Final Report 2004, USAID, Washington, http://pdf.usaid.gov/pdf_docs/Pnacx726.pdf)

${ }^{122}$ REGULATION NO. 2001/13, UNMIK/REG/2001/13, 15 June 2001, On the Establishment of Radio-Television of Kosovo,

http://www.unmikonline.org/regulations/unmikgazette/02english/E2001regs/RE2001_13.pdf

${ }^{123}$ Law on Radio Television of Kosovo, Article 19, 19.1, http://www.kuvendikosoves.org/common/docs/ligjet/2006_02-L47_en.pdf

124 Law on Radio Television of Kosovo, Article 20, 20.5 
In the first year of the functioning of the RTK based on the new law there were no changes to the amount of the subscription fee of $€ 3.5$ or of the collection agent. In 2007 RTK became a company that was financially independent by the state budget or donor money.

Exactly on the year when the RTK achieved an almost complete financial independence, changes that would be reflected on its funding model began. According to the law, the changes that appeared as decisions should stem from the Founder (the Assembly of Kosovo) and RTK, as stipulated by Article 20, items 20.1 and 20.2. However, these changes were not put in place by these two institutions but by the collection agent - the Kosovo Energy Corporation ${ }^{.125}$ The matter ended up with the Constitutional Court of the Republic of Kosovo, at the initiative of a citizen who considered the RTK subscription fee as anti-constitutional. "The legal battle" was concluded with the removal of the RTK subscription fee ${ }^{.126}$

The decision of the Constitutional Court should have influenced on the Assembly of the Republic of Kosovo, as a founding institution, to expedite procedures for the adoption of the new legal grounds that would provide a solution to the long-term financing of the RTK. Instead, the Assembly and the governing coalition comprising of the two main political forces in Kosovo (PDKLDK) decided on another way. The Assembly adopted a temporary solution for the direct funding from the state budget for the first six months of 2010. On 28 January 2010, the Assembly adopted Decision No. 03'237 on the temporary funding of the RTK from 1 January 2010 to 30 June 2010. This funding qualified as temporary was repeated until the adoption of the new law. The funding scheme in 2010 changed and the public broadcaster entered in the funding scheme directly from the state budget. The financial independence was lost and the "short-term" funding solution created the dependence of RTK on the political will of the Assembly and of the Government, as a pre-condition for the interference of the political power in the editorial policies of RTK. The Assembly kept in effect until 2012 the previous law, although the reality was already different and the law was not applied.

\section{RTK with a law from the Assembly of the Republic of Kosovo}

"Legal instruments designed to give politicians influence over strategic matters might instead be used to pressure the broadcaster's day-to - day affairs." ${ }^{27}$ Hanretty and other scholars link the political interferences in public broadcasters with the level of professionalization in such broadcasters and with the respective legal protection. "The greater the legal protections given to the broadcaster, the more limited the opportunities for interference." 128

In the case of RTK, the legal protection as a restrictive element for political interference lacked from its establishment. Since 2001 RTK had the legal grounds regulating its functioning but the existing legal grounds failed to ensure the independence of the broadcaster from politics, either because of the legal provisions (Regulation 2001/13), or because of the failure to apply the legislation (Law No. 02 / L - 47). The simple fact that the authority that established the RTK - the Assembly of the Republic of Kosovo, left in effect the Law No. 02 / L - 47 in spite of the termination of the subscription fee for the RTK demonstrates the negligence and the lack of willingness on the part of the political power to establish sound legal grounds as a pre-condition for the independence of the public broadcaster.

${ }^{125}$ In the first decade after the war, Kosovo experienced many issues with electric energy supply and faced the refusal of citizens to pay for a service they did not benefit from on regular basis. The RTK fee was added and the citizens were unhappy. Their lack of satisfaction related to the RTK program and the fact that the citizens did not want to pay for the program, as well to the fact that they requested the program to be free of charge, and to the fact that certain areas were not covered by RTK signal.

${ }^{126}$ On 16 October 2009, the Constitutional Court ruled on an interim measure on further application of Article 20.1 of the Law on the Radio Television of Kosovo, whereas the Assembly of Kosovo was recommended to review the nature of Article 20.1 and practices based on that article, no further than 1 December 2009. This measure was upheld by final ruling on the case. To read more about the ruling of the Constitutional Court see: Constitutional Court of the Republic of Kosovo, Decision to remove from the list the request in Case No. KI 11/09, Ref. No.: VHL112/11, 30 May 2011, http://www.gjk-s.org/repository/docs/gjk_ki_11_09_shq.pdf

127 Hanretty, C., Public broadcasting and political interference, Taylor \& Francis e-Library, pg 7

128 Ibid., pg 4 
The need for a law for the RTK became a necessity due to the instable funding for the RTK based only on the state budget line. In the first y ear with primary state budget funding, RTK emphasized the importance of finding sustainable funding and the inclusion of this change in the new law. The Chairperson of the Board, Rrahman Paçarizi, emphasized that the public status of the RTK was endangered by the lack of sustainable funding in compliance with the international standards and best practices. "For this reason, the Assembly of Kosovo, as the founder of the RTK is the authority to undertake all necessary actions to ensure the adoption of the new Law on RTK, which will create opportunities for sustainable funding not from the budget of Kosovo, which is the basic pre-condition to ensuring the editorial independence as one of the essential obligations of the Radio Television of Kosovo." 29 The funding matter was one of the two main issues on focus of the public and parliamentary discussions on the new law that was submitted for adoption to the Assembly of the Republic of Kosovo only in June 2011. The Assembly adopted in principle the draft-law on the public broadcaster on 29 June 2011. The most debatable issues in the parliamentary sessions were the ones on the funding and the opening of the second channel of RTK in Serbian language. In spite of the expectations that the law would receive final approval in the spring session in 2011 , this did not happen because it was considered that the draft-law required more time to be prepared. The Assembly of the Republic of Kosovo adopted the Law on the Radio Television of Kosovo on 29 March 2012 and it was promulgated by the President, Atifete Jahjaga, on 12 April 2012. ${ }^{130}$

\subsection{Funding of RTK according to the Law No. 04 / L - 046}

The Law No. 04/L-046 introduced changes how funds were allocated for the Radio Television of Kosovo but still kept the funding of the public broadcaster by the state budget for a period of up to three years. ${ }^{131}$ "For a transitional three-y ear period, until the solution of funding through subscription, RTK will be allocated $0.7 \%$ of this income from the Kosovo Budget annually, excluding incomes from the privatization process, one time incomes for the Budget of Kosovo and incomes of central and local level". ${ }^{132}$ Such method of funding until the next three years provided an opportunity for the parties to find in the meantime the appropriate model of funding based on subscription. However, it proved that although a long period of time had passed, the stakeholders involved in the discussion on this Law still had failed to harmonize the positions and did not achieve any agreement on the RTK funding scheme where the main source of revenue would be to return the subscription. Article 22 of Chapter IV of the Law determined the conditions and timeframes for the parties that had to find the right way to collect the RTK fee and its amount. The founders (the Assembly of the Republic of Kosovo) were assigned the right to determine the amount of the RTK fee but the RTK Board had the right to propose the amount. According to the Law, these actions were supposed to occur within 12 months from the time the Law entered into effect. Following the approval of the mechanism to collect the fee and of the fee amount the Assembly would review the funding by the Budget of Kosovo. This change did not happen within the foreseen deadlines. RTK funding remained as per Paragraph 4 of Article 21, for the period which in the Law in envisaged as a transitory period, up to three years. ${ }^{133}$ Based on the developments on RTK and within this institution, the failure to apply these legal requirements is attributed to several factors simultaneously. Following the issues and concerns with the collection agency (KEC) during the period under the previous law, the RTK was challenged by finding a mechanism to collect the fee on its behalf. Other factors that influenced were the

\footnotetext{
${ }^{129}$ Extract from the speech of the Chairperson of the Board of RTK in the RTK Annual Report 2010, www.rtklive.com/Raportet Vjetore

${ }^{130}$ The Law on the Radio Television of Kosovo No. 04 / L - 046, Official Gazette of the Republic of Kosovo No. 7 / 27 April 2012, Prishtina

131

http://www.kuvendikosoves.org/common/docs/ligjet/Law\%20on\%20Radio\%20Television\%20of\%2

0Kosova.pdf

${ }^{132}$ Law on Radio Television of Kosovo, Chapter IV, Funding of the RTK, Article 21. 4

${ }^{133}$ Until October 2015 (the time when this paper was finalized), neither the RTK Board nor the Assembly of the Republic of Kosovo have undertaken the actions required by the law of 2012. This issue has been raised several times by the RTK Board and Management as a request to resolve the matter of the long-term funding of RTK, but there have been no concrete public and official proposals for the obligations stemming for them from the law.
} 
circumstances created by the relations between the main political parliamentary forces and the RTK. In 2013 - 2015, the opposition has criticized the RTK in continuity for its approach to the editorial policy as a media pro the governing coalition. In the meantime, the governing coalition itself (PDK AKR - minorities) had in the respective period continuous issues with ensuring the parliamentary majority. The RTK Board and M anagement faced during that time many concerns within the company expressed in particular by one of the trade unions functioning under the auspices of the RTK. The RTK management itself did not consider as a matter of priority the transition from funding by the Kosovo Budget to subscription based funding. One of the studies on RTK assesses as a matter of concern the lack of willingness on the part of the RTK management to propose the return to the subscription system. "It appears that the RTK management feels comfortable with the status-quo and doesn't want to go back to the subscription fee. Mentor Shala, the director general of RTK claims that: "the current financing form is the most suitable." He argues that the potential political influence would continue even if RTK switched to a subscription fee, since RTK would still be obliged to report to the Assembly! Therefore, he say s, "this (direct funding from the Assembly) is the most secure form of financing as it never leaves the public broadcaster without income. ${ }^{134}$

\subsection{Hection of RTK management bodies according to the Law No. 04/L-046}

The legal grounds are used an as efficient instrument of influence on the part of state institutions and great political forces on specific media. This instrument when raised to the level of legal obligations is applied through the method of selection or the appointment of leaders of media established by a state institution. The political control of the media through appointments is made in particular in public broadcasters. In the case of the Radio Television of Kosovo, the Law No. 04 / L - 046 created an opportunity for the elected political representatives in the Assembly of the Republic of Kosovo to exert direct influence on the composition of the RTK managing body. The law changed the method of selection of the members of the RTK Board compared to the previous Law and concentrated the entire process at the Assembly. The Independent Media Commission and its ad hoc committee, which comprised of representatives from the Academy of Sciences and Arts of Kosovo was excluded from the selection process, and all competences for the selection of the Board were given to the members of the Assembly. Article 25 determines the composition of the RTK Board as well as the criteria to be met by the candidates for Board members. The Law determined a Board of 11 members, adding two members to the previous Board composition according to the previous law. "Board members shall be individuals with credibility and high human, professional and moral authority. During their work, board members shall be fully dedicated, objective and impartial". ${ }^{135}$

Article 26 defines the procedures for the selection of 11 members, clearly defining in item one that the members of the RTK Board are nominated by the Assembly of Kosovo. All applications without any preliminary selection by any independent body or committee go to the legislative institution and to the elected political representatives. "Five (5) days prior to closure of public advertisement, RTK shall submit all applications to the Kosovo Assembly, which establishes an ad-hoc Committee to review them; Within a period of thirty (30) days, when the deadline has already been closed for the new applicants and subsequent interviewing of two (2) candidates shall be recommended by the Committee for each Board positions, who are considered the most suitable based on their competencies, integrities and commitment to develop and advance RTK. By determining in this way the selection of the members of the RTK board, politics exerts direct influence on the public broadcaster. In a country with a frail democracy and in a politicized context, people who are independent of politics should "lobby" throughout the entire process and be subjected to the political evaluation should they wish to become Board members and take over a duty throughout the duration of which they are required to "act in their personal capacity and not represent any interest outside of RTK with the exception of the public interest". Can this be achieved in a society like the one in Kosovo, where according to the assessments from independent organizations, the political decision

\footnotetext{
${ }^{134} \mathrm{Miftari}$, N., Starting from scratch: The role of media assistance in the establishment of independent media institutions in Kosovo, Democracy for development, ANALITIKA, Sarajevo / Prishtina 2013, http://www.analitika.ba/sites/default/files/publikaciie/miftari_n_- 
making bodies influence the independent institutions? In principle, the answer to this question would be no; however the practice of electing the RTK Board members in accordance with this Law has continuously presented issues. Several times, none of the candidates who made it to the voting stage at the Assembly sessions failed to get the necessary majority of votes from the members of the Assembly, and for this reason the vacancy announcements were cancelled. There have been instances when among the individuals who failed to get votes there were public figures, who for years were known by the public opinion as being politically impartial. On the other hand, the Law has produced a Board composition that has either demonstrated political bias, or lack of professional capacities. Through this law, the coalitions in power have created room for themselves to exert direct influence on the top level management and structure of the public broadcaster thus engendering a dependency of the management of the broadcaster on the will of the parliamentary majority.

This dependency is apparent in the process of the dismissal of Board members. According to the law, to conclude the dismissal initiative, the simple parliamentary majority is needed. The subjects of the governing coalition may use this legal possibility even in the cases when a Board member refuses to be subjected to them.

The Law renders the RTK Board a weak and powerless body in the face of powerful political forces. However, the Board is the highest authority for decisions within and for the RTK. Influenced by politics, the Board influences on the internal strategic development of the RTK. In addition, the Board appoints and dismisses the General Director of RTK; appoints and dismisses the general deputy directors, directors of the radios and televisions by a simple majority of votes, upon the proposal of the General Director; ap proves the organizational structure and the programming concept of RTK, as well as reviews and approves the annual budget.

\section{The Law as an instrument to influence the editorial policies}

In the case of the Radio Television of Kosovo, the political subjects that have the most power have selected the legal grounds for the functioning of the public broadcaster as the main option to create its dependency through two main components: financing and selection of the managing body. Through the Law of 2012, politics has in particular created room to influence the public broadcaster by centralizing the process for the selection of the Board members only at the level of the RTK founder - the Assembly of Kosovo, as an institution comprising of political representatives. By exerting strong influence on the process of selection and by creating legal conveniences to dismiss members of the RTK Board, on which depends the internal functioning of the broadcaster, the simple parliamentary majority usually comprising of the parties of the governing coalition ensures its influence on the editorial policies of the public broadcaster.

Through its definitions the Law No. 04 / L - 046 does not provide adequate legal protection for the public broadcaster in Kosovo, and does not guarantee its financial and editorial independence. Although such legal grounds define RTK as a public broadcaster, they determine its functioning as a media outlet in the function of political subjects that compose the parliamentary majority, namely the subjects of the governing coalition. 


\section{Recommendations}

- To prepare a new law on the Radio Television of Kosovo. Amending the current law would not be sufficient because it is necessary to make amendments throughout the entire structure of the law, in particular in its most important parts that determine the strategic development and the rapport between politics and the public broadcaster.

- While preparing the new law on the public media in Kosovo, to ensure broad inclusion of the civil society and media experts. Their inclusion is a process in compliance with the legal status of the public media and would help create legal grounds to enable the transformation of the RTK in accordance with its legal status.

- The new law would determine subscription as a long-term solution for the funding of RTK and would clearly determine the timeframe of RTK to achieve contractual agreements with the subscription fee collecting agency and the amount of the fee.

- The Law should change the method for the selection of the RTK managing bodies. The election of the Board should be "decentralized", i.e. be taken away from the direct political decision-making at the Assembly of Kosovo and by including social actors (important independent and social institutions).

- The Law should determine the editorial principles of RTK, which should be obligated to reflect in its programs the objective social reality and steer away from being a messenger of the protocol-type reporting, promoting daily activities reporting, and empowering the voice of the political power.

- The new Law should keep the status of the public media for the RTK but determine external public mechanisms to assess the quality and content.

- In its entirety the new Law on RTK should create strong grounds to protect the public broadcaster by the political power and its transformation into a real public media outlet.

\section{References}

1. Doyle Gillian, Understanding media economics, Second edition, SAGE Publication Ltd, London 2013

2. Hallin David, Mancini Paolo, Comparing Media Systems - Three models of media and politics, Cambridge University Press, UK 2004

3. Hanretty Chris, Public broadcasting and political interference, Taylor \& Francis e-Library, ISBN: 978-0-203-81372-0, 2011

4. Kuhn Raymond, Broadcasting and politics in Western Europe, Frank Cass and Company Limited, London 1985

5. Kunczik Michael, Zipfel Astrid, Uvod u znanost o medijima i komunikologiju, Zaklada Friedrich Ebert, Zagreb 2006

6. McChesney W Robert, Pickard Victor, Will the last reporter please turn out the lights - the colapse of journalism and what can be done to fix it, The new press, New York 2011

7. Benson Rodney, Powers Matthew, Public Media and political independence: Lessons for the Future of Journalism from Around the World, New York University Department of Media, Culture and Communication, february $2001 \mathrm{http}: / / \mathrm{www}$.freepress.net/sites/default/files/stnlegacy/public-media-and-political-independence.pdf

8. Miftari, Naser, Starting from scratch: The role of media assistance in the establishment of independent media institutions in Kosovo, Democracy for development, ANALITIKA, Saraievo / Prishtina 2013. http://www.analitika.ba/sites/default/files/publikacije/miftari_n__rrpp_kosovo_wp04_3dec2013_final_for_publishing.pdf

9. Kaufman, Joshua, Kosovo media assessment, Final Report 2004, USAID, Washington, http://pdf.usaid.gov/pdf_docs/Pnacx726.pdf

10. Regulation No. 2001/13, UNMIK/REG/2001/13, 15 June 2001, On the Establishment of Radio Television of Kosovo, http://www.unmikonline.org/regulations/unmikgazette/02english/E2001regs/RE2001_13.pdf 
11. Ligji Nr. 02/L-47, Ligji për Radiotelevizionin e Kosovës, Kuvendi i Kosovës, 20 janar 2006, http://www.kuvendikosoves.org/common/docs/ligjet/2006_02-L47_en.pdf

12. Ligi Nr. 04 / L - 046, Ligii për Radiotelevizionin e Kosovës, Gazeta Zyrtare e Republikës së Kosovës, Nr. 7 /27 prill 2012, Prishtinë

13. Gjykata Kushtetuese e Republikës së Kosovës, Vendim për heqjen nga lista të kërkesës në Rastin, Nr. KI 11/09, Nr. ref.: VHL112/11, 30 maj 2011,

14. http://www.gjk-ks.org/repository/docs/gjk_ki_11_09_shq.pdf

\section{RTK Annual Reports:}

1. Raporti Vjetor 2001, http://www.rtklive.com/rtk/rp_ad_sq/2001_sq.pdf

2. Raporti Vjetor 2002, http://www.rtklive.com/rtk/rp_ad_sq/2002_sq.pdf

3. Raporti Vjetor 2003, http://www.rtklive.com/rtk/rp_ad_sq/2003_sq.pdf

4. Raporti Vjetor 2004, http://www.rtklive.com/rtk/rp_ad_sq/2004_sq.pdf

5. Raporti Vjetor 2005, http://www.rtklive.com/rtk/rp_ad_sq/2005_sq.pdf

6. Raporti Vjetor 2006, http://www.rtklive.com/rtk/rp_ad_sq/2006_sq.pdf

7. Raporti Vjetor 2007, http://www.rtklive.com/rtk/rp_ad_sq/2007_sq.pdf

8. Raporti Vjetor 2010, http://www.rtklive.com/rtk/rp_ad_sq/2010_sq.pdf 